\title{
NITROGEN EFFECIENCY IN BARELY UNDER SALINE-SODIC CONDITIONDS AS AFFECTED BY UREA, COMPOST AND BIOFERTILIZER (Rhizobium radiobacter $\mathrm{sp}$.) \\ Helmy, A. M. ${ }^{1}$; M. K. Abdel Fattah ${ }^{1}$ and Kh. A. Shaban ${ }^{2}$ \\ ${ }^{1}$ Soil Science Dept., Fac. Agric., Zagazig Univ., Zagazig, Egypt \\ ${ }^{2}$ Soil, Water and Environmental Res. Institute, ARC, Giza, Egypt
}

\begin{abstract}
Effects of application of different rates of urea, biofertilizer, (Rhizobium radiobacter sp.) as salt tolerant PGPR strain and compost on barley (Hordeum valgare $L$. cv. Giza 126) were studied on a saline-sodic sandy loam soil at Gelbana village, Northern Sinai Governorate, Egypt during the two successive winter seasons of 2011/2012 and 2012/2013. The studied treatments were No, control (non fertilized), $\mathrm{N} 1$, mineral- $\mathrm{N}\left(119 \mathrm{~kg} \mathrm{~N}^{-1}\right)$, N2, mineral- $\mathrm{N}\left(179 \mathrm{~kg} \mathrm{~N}^{-1}\right)$, equivalent 0,50 and $75 \%$ from recommended rate for barley, biofertilizer (Bio), biofertilizer (Bio) $+\mathrm{N} 1$, biofertilizer (Bio) $+\mathrm{N} 2$, compost, compost $+\mathrm{N} 1$ and compost $+\mathrm{N} 2$. The results could be summarized as follow: available $\mathrm{N}, \mathrm{P}, \mathrm{K}, \mathrm{Fe}, \mathrm{Mn}$ and $\mathrm{Zn}$ concentrations were significantly increased due to the above mentioned treatments. On the other hand, the electrical conductivity $\left(\mathrm{EC} \mathrm{dSm}^{-1}\right)$ and soil $\mathrm{pH}$ values decreased due to these treatments. The applied urea, compost and biofertilizer as well as their combinations significantly, increased straw and grain yields as well as $\mathrm{N}, \mathrm{P}, \mathrm{K}, \mathrm{Fe}, \mathrm{Mn}$ and $\mathrm{Zn}$ contents in straw and grains, grain weight spike ${ }^{-1}$ and 1000 -grain weight in the two growing seasons, except grains spike ${ }^{-1}$ which did not reach the level of significantly in the first season. The highest values of nitrogen use efficiency (NUE), nitrogen agronomic efficiency (NAE) and apparent nitrogen recovery (ANR) were obtained due to the treatment Biofertilizer $+\mathrm{N} 1\left(119 \mathrm{~kg} \mathrm{~N} \mathrm{ha}^{-1}\right)$. The higher rate of $\mathrm{N}$ fertilization i.e., $179 \mathrm{~kg} \mathrm{~N}$ ha $^{-1}$ combined with compost was of superior effect on improving soil chemical properties and increasing barley production, protein content and nutrient uptake as compared to the other treatments. This was found to be true for straw and grains. Thus, it is suggested to use a combination of organic and inorganic fertilizers to achieve the highest yield without negative effect on grain quality.
\end{abstract}

Keywords: Saline-sodic soil, urea, biofertilizer, compost and barley.

\section{INTRODUCTION}

Solving the problem of shortage in food production to face the demand of fast growing population is a national goal for the Egyptian Government. Therefore, increasing the productivity of crops, such as cereals especially wheat and barley became a necessity to minimize the gap between our total production and consumption. Many researchers paid a great attention to increase the productivity of barley per unit of cultivated area through mineral fertilization. Such a fertilization practice although increases grain yield, yet this occurs at the expense of both soil health and environment. It is now unanimously agreed that decreasing fertilizer use efficiency (FUE) and declining soil organic matter (SOM) levels are serious threats to sustainability. The combined use of organic manures and inorganic fertilizers influences the physical, chemical and biological properties of the soil and 
Helmy, A. M. et al.

plays an important role in energy flow and nutrient cycling. It does not only sustain higher levels of productivity, but also improves soil health and enhances nutrient use efficiency (Palm et al., 2001). If soil biodiversity is the guardian of soil fertility and the health of the soil and crops, then frequent additions of fresh organic matter are the guardians of soil biodiversity (Krupenikov et al., 2011). Many of the characteristics of highly productive soils relate to the organic fraction of the soil, especially as continued crop production potential has a direct relationship with its organic matter content (Mann et al., 2002).

The adoption of management practices such as crop residue treatment, the use of catch crops, or the appropriate timing and amount of manure application determines the degree to which yields and nutrient losses are affected (Doltra et al., 2011). Residue harvest removes more nutrients from the agro-ecosystem than grain harvest alone (Andrews, 2006). After a longterm experiment, Kas et al. (2010) concluded that the incorporation of cereal straw as the only source of organic fertilization sustained wheat and barley yields near the production level of the system. Montemurro et al. (2006) indicated that the partial substitution of mineral $\mathrm{N}$ with organic $\mathrm{N}$ did not reduce yields and that $\mathrm{N}$ utilization and mixed fertilization resulted in a good balance between productive parameters, $\mathrm{N}$ utilization efficiency indices and soil $\mathrm{N}$ deficit, while also involving lower pollution risks. The combined application of chemical fertilizer and maize straw with a wide $\mathrm{C} / \mathrm{N}$ ratio is an important way of reducing the superfluous accumulation of $\mathrm{N}$ fertilizer (Lu et al., 2010).

Soil salinity is one of the important factors affecting growth and yield of most crops. Many workers reported that application of organic manure and bio-fertilizer can alleviate the adverse effects of soil salinity on both soil and the grown plants. In this concern, Poraas et al. (2008) stated that maize grain yield, 100 grain weight and stover yield which grown on saline soil $\left(E C \mathrm{dSm}^{-1}\right.$ in soil paste, 10.7) were significantly increased due to organic and bio treatments. Omran et al. (2009) reported that the interaction effect between FYM with $50 \%$ of the recommended dose of $\mathrm{N}$ and bio-fertilizer inoculation induced significant increase in growth parameters, seed quality and seed chemical compositions of flax seeds grown on sandy soil. Berhanu et al. (2013) found that organic fertilizer sources (i.e, plant residues and FYM) greatly enhanced the grain yield and yield components of wheat grown on brown forest soil.

The present work aims at identifying the effective role of applied organic compost and bio-inoculation with Rhiobium radiobacter sp strain (salt tolerant PGPR) applied solely or in combination with chemical-N fertilizer (urea) on maximizing the productivity of barley plants grown under saline-sodic soil condition. Evaluating the optimal use of nitrogen fertilizer when combined with the abovementioned treatments on barley yield and its quality as well as its contents of some nutrients beside of the implications of the used treatments on some soil properties were also taken into consideration in this study. 


\section{MATERIALS AND METHODS}

A filed experiment was carried out on a saline-sodic sandy loam soil at Gelbana village, North Sinai Governorate, Egypt during the two successive winter seasons of 2011/2012 and 2012/2013, using a randomized complete block design with three replicates. The purpose of this experiment to evaluate the effect of biofertilizer (Rhizobium radiobacter strain, salt tolerant PGPR), urea (460 $\mathrm{g} \mathrm{N} \mathrm{kg}^{-1}$ ) and organic fertilizer (compost) on grain quality, productivity and contents of some macro $(\mathrm{N}, \mathrm{P}$ and $\mathrm{K})$ and micro $(\mathrm{Fe}, \mathrm{Mn}$ and $\mathrm{Zn}$ ) nutrients of barley plants. Also, soil properties after harvest were taken into consideration. A representative soil sample of the field was taken from 0 - $30 \mathrm{~cm}$ layer and used for determining some physical and chemical properties of studied soil whose results are presented in Table 1.

The soil experimental filed was pre-treated by applying the gypsum requirements then ploughing soil to a depth of $30 \mathrm{~cm}$. Therefore, continuous leaching process was carried out through adding water to soil basins until it reaches a height of $15 \mathrm{~cm}$ above the soil surface. Such height of water was kept constant for 3 days. Two weeks after the leaching process lazar technique was used for leveling the soil surface followed by deep sub-soiling, plowing and establishing field drains at a depth of $90-\mathrm{cm}$ at the beginning of each drain followed by establishment of an irrigation canal in the middle part of the experimental area. The soil was irrigated from El-Salam Canal (a mixture of Nile water and agricultural drainage water), (Table 2).

Organic compost was prepared using two tons of air-dried straw residues (rice straw, maize stover and faba bean straw) and its chemical composition is shown in Table 3.

Barley seeds (Hordeum valgare cv. Giza 126) were inoculated with biofertilizer which was prepared from Rhiobium radiobacter sp strain (salt tolerant plant growth promoting rhizobacteria, PGPR) isolated from the rhizosphere soil of Sahl El-Tina location and deposited in Gene bank under number of HQ395610 Egypt by Bio-fertilizer Production Unit, Department of Microbiology, Soils, Water and Enviro. Res. Inst., Agric. Res. Center, Giza, Egypt. Rhizobia inoculant was applied at a rate of $100 \mathrm{~g}$ of the inoculant for 15 $\mathrm{kg}$ seeds wetted with $300 \mathrm{ml}$ of adhesive. The moist seeds were thoroughly mixed with the inoculants in the shade, sown immediately and covered with soil in order to minimize Rhizobia exposure to the sun. Seeds of barley were sown, $20^{\text {th }}$ and $25^{\text {th }}$ of October $2011 / 2012$ and 2012/2013, respectively. The inoculation of the Rhizobia strain was added 3 times at 21, 45 and 65 days after planting at rate of $12 \mathrm{~L}$ of the inoculant suspension / $950 \mathrm{~L}$ water ha ${ }^{-1}$. 
Helmy, A. M. et al.

Table 1. Physical and chemical properties of the investigated soil

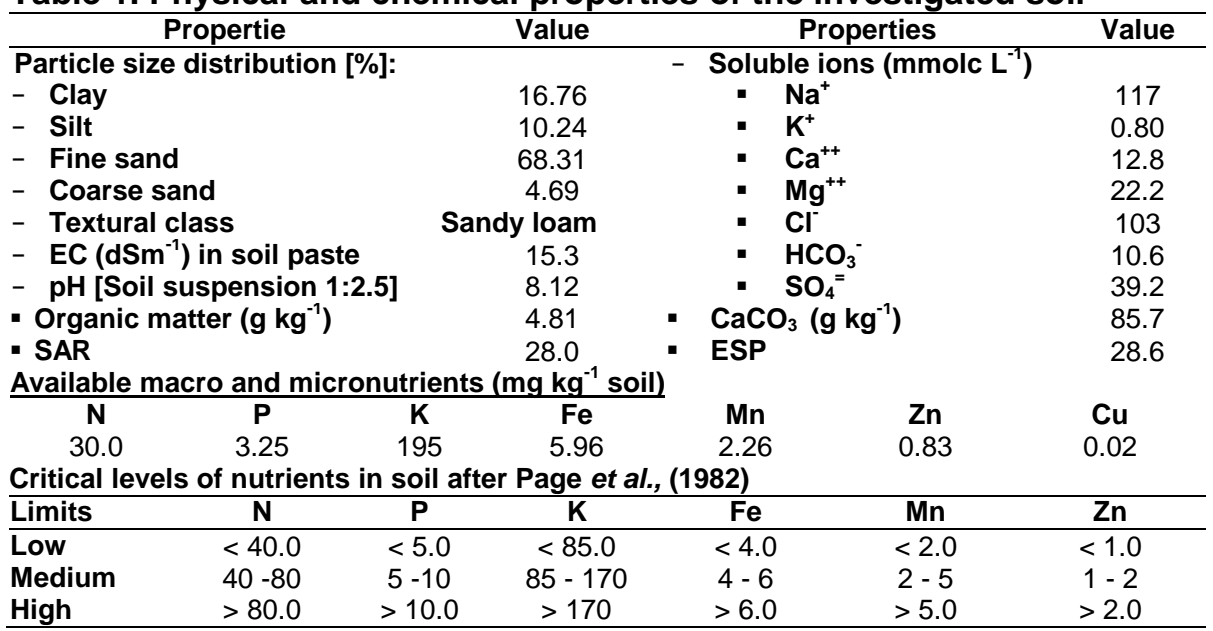

Table 2. Chemical properties of the irrigation water in the two successive years of study.

\begin{tabular}{lccc}
\hline & Properties & \multicolumn{3}{c}{ Season } \\
\cline { 2 - 4 } pH & $\mathbf{2 0 1 1 / 2 0 1 2}$ & $\mathbf{2 0 1 2 / 2 0 1 3}$ & Average \\
EC $\left(\mathbf{d S m}^{-1}\right)$ & 7.89 & 7.93 & --- \\
& 1.46 & 1.32 & 1.39 \\
$\mathbf{N}-\mathbf{N H}_{4}{ }^{-}$ & Macronutrient $\left(\mathbf{m g ~ k g}^{-1}\right)$ & & \\
$\mathbf{N}-\mathbf{N O}_{3}{ }^{-}$ & 7.99 & 6.55 & 7.27 \\
$\mathbf{P}$ & 7.32 & 7.68 & 7.50 \\
$\mathbf{K}$ & 2.08 & 2.14 & 2.11 \\
& 9.02 & 9.08 & 9.05 \\
$\mathrm{Fe}$ & Micronutrient $\left(\mathbf{m g ~ k g}^{-1}\right)$ & & \\
$\mathbf{M n}$ & 0.97 & 0.86 & 0.92 \\
$\mathbf{Z n}$ & 1.32 & 1.35 & 1.34 \\
\hline
\end{tabular}

Table 3. Chemical properties of the compost used in the study.

\begin{tabular}{|c|c|c|c|c|c|c|c|c|c|c|}
\hline \multirow[t]{2}{*}{ Property } & \multirow{2}{*}{$\begin{array}{c}\text { pH } \\
(1: 2.5)\end{array}$} & \multirow{2}{*}{$\begin{array}{c}E C \\
d^{-1} \\
(1: 10)\end{array}$} & \multirow[t]{2}{*}{ O.C } & \multirow{2}{*}{$\begin{array}{l}\mathrm{C} / \mathrm{N} \\
\text { ratio }\end{array}$} & \multicolumn{3}{|c|}{$\begin{array}{c}\text { Total macronutrients } \\
\left(\mathrm{g} \mathrm{kg}^{-1}\right)\end{array}$} & \multicolumn{3}{|c|}{$\begin{array}{c}\text { Total micronutrients } \\
\left(\mathrm{mg} \mathrm{kg}^{-1}\right)\end{array}$} \\
\hline & & & & & $\mathbf{N}$ & $P$ & $\mathrm{~K}$ & $\mathrm{Fe}$ & $\mathrm{Mn}$ & $\mathrm{Zn}$ \\
\hline Compost & 7.95 & 4.60 & 35.7 & 23.6 & 15.1 & 6.61 & 18.6 & 699 & 431 & 286 \\
\hline
\end{tabular}

The treatments were arranged in a randomized complete block design with three replicates. The plot area was $40 \mathrm{~m}^{2}(4 \mathrm{~m}$ width and $10 \mathrm{~m}$ length). Soil was amended with compost 20 days before sowing at a rate of 6 Mega gram (Mg) ha ${ }^{-1}$ and ordinary superphosphate $\left(67.6 \mathrm{~g} \mathrm{P} \mathrm{kg}^{-1}\right)$ at a rate of $31 \mathrm{~kg} \mathrm{P} \mathrm{ha}^{-1}$ during seed bed preparation. Also, all treatments received potassium fertilizer $60 \mathrm{~kg} \mathrm{~K} \mathrm{ha}^{-1}$ as potassium sulphate $\left(400 \mathrm{~g} \mathrm{~K} \mathrm{~kg}^{-1}\right)$ in two equal doses at 21 and 42 days after planting. All normal agricultural practices recommended for the region were applied. Nitrogen fertilizer was applied as urea, $460 \mathrm{~g} \mathrm{~N} \mathrm{~kg}^{-1}$ at three rates 0,119 and $179 \mathrm{~kg} \mathrm{~N} \mathrm{ha}^{-1}$ equivalent 0,50 and $75 \%$ from recommended rate for barley in three equal doses; started 
before planting, then 30 and 50 days after planting. The experiment treatments were as follow:

1- No, control (non-treated)

2- $\mathrm{N} 1$, mineral- $\mathrm{N}\left(119 \mathrm{~kg} \mathrm{~N} \mathrm{ha}^{-1}\right)$

3- N2, mineral- $\mathrm{N}\left(179 \mathrm{~kg} \mathrm{~N} \mathrm{ha}^{-1}\right)$

4- biofertilizer, (Bio), by inoculation with Rhizobium radiobacter strain (PGPR) as a salt tolerant rhizobacteria.

5- Bio + N1

6- Bio + N2

7- compost (6 Mega gram, $\left.\mathrm{Mg} \mathrm{ha}^{-1}\right)$, Mega gram $=10^{6} \mathrm{gram}=$ Metric ton

8- compost $+\mathrm{N} 1$

9- compost $+\mathrm{N} 2$

Harvest was done on, $27^{\text {th }}$ of April and, $2^{\text {nd }}$ of May 2011/2012 and 2012/2013, respectively.

\section{Dry matter and grain yield}

At harvest, ten plants were taken randomly from each plot and tagged for yield assessment. Grain weight spike ${ }^{-1}$ and 1000-grain weight were measured. Total proline content was determined according to Bates et al. (1973). In addition, plants in an area of $2 \mathrm{~m}^{2}$ of each plot were harvested, air dried, then straw yield, grain yield, biological yield were estimated. Representative ten plants were taken and the following parameters were calculated:

$>$ Grain protein contents by multiplying grain N\% by 5.83 (Baker, 1979).

$>$ Grain protein yield in $\mathrm{kg} \mathrm{ha}^{-1}$ \{protein content $\mathrm{g} \mathrm{kg}^{-1} \times$ grain yield $\mathrm{Mg} \mathrm{ha}^{-1}$ \}

$>$ Harvest Index (HI): (grain yield / biological yield) x100

$>$ Yield efficiency: (grain yield / straw yield) $x 100$.

$>$ Apparent $N$ recovery (ANR) by the equation described by Echeverria and Videla (1998), i.e., ANR $=[\mathrm{N}$ uptake (fertilized plot) $-\mathrm{N}$ uptake (zero plot) / $\mathrm{N}$ fertilizer rate] $\mathrm{X} 100$.

> Nitrogen agronomic efficiency (NAE) for $\mathrm{N}$ according to Craswell and Godwin (1984): [grain yield (fertilized plot) - grain yield (zero plot)] / N fertilizer; yield and $\mathrm{N}$ fertilizer in $\mathrm{kg} \mathrm{ha}^{-1}$.

> Nitrogen use efficiency (NUE) is the $\mathrm{N}$ applied to produce yield and is defined here as the amount of grain yield per unit of applied $\mathrm{N}$ ( $\mathrm{kg}$ of grain yield $\mathrm{kg}^{-1}$ of $\mathrm{N}$ applied) as described by Angas et al. (2006).

Macro and micronutrients content of seeds and pod samples were determined in aliquots of digested solutions resulting from the digestion of grains and pod samples by a mixture of $\mathrm{H}_{2} \mathrm{SO}_{4}$ and $\mathrm{HClO}_{4}$ acids after drying in an oven at $70^{\circ} \mathrm{C}$ as described by Ryan et al. (1996).

\section{Soil characteristics}

After harvest, representative soil samples of the field were taken $(0-30$ $\mathrm{cm}$ layer) from each plot. Samples were analyzed for EC (in soil paste extract), $\mathrm{pH}$ (in 1: 2.5 soil: water suspension) according to Page et al. (1982). Available nitrogen was extracted by $\mathrm{KCl} 2 \mathrm{~N}$ extract and determined by steam distillation procedure using MgO- Devarda alloy according to Bremner and Keeney method's described by Black et al. (1982). Available phosphorus was extracted using $0.5 \mathrm{~N} \mathrm{Na} \mathrm{HCO}_{3}$ solution at $\mathrm{pH} 8.5$ and determined colorimetrically according to Watanabe and Olsen (1965). Available potassium was extracted using $1 \mathrm{~N}$ 
Helmy, A. M. et al.

ammonium acetate at $\mathrm{pH} 7.0$ and determined photometrically according to Jackson (1958). Available iron, manganese and zinc were extracted by DTPA and measured using atomic absorption spectrophotometer as described by Soltanpour, (1985).

\section{Statistical analysis}

Data of the two seasons were subjected to statistical analysis of variance (ANOVA), and the least significant differences (L.S.D) at $5 \%$ level according to Snedecor and Cochran, (1971).

\section{RESULTS AND DISCUSSION}

\section{Effect of treatments on some soil chemical properties after barley harvest \\ Soil pH}

Data in Table 4 show the effect of mineral, bio. and organic-N fertilization on some chemical properties of the soil at the end of the experiment. The values of $\mathrm{pH}$ were slightly decreased as affected by all the studied treatments for the two seasons. These results are in agreement with those of Siam et al. (2013) who reported that the decrease in $\mathrm{pH}$ was marked particularly when $\mathrm{N}$ and compost fertilization were combined. The highest decrease in $\mathrm{pH}$ value was achieved by treating the soil by compost $+\mathrm{N} 2$. Such decreases in soil $\mathrm{pH}$ might be attributed to the effect of microorganisms on decomposing organic matter releasing organic acids and producing several phytohormones such as indole acetic acid and cytokinins. These results are similar to those obtained by Ashmaye et al. (2008) and Abdel-Fattah (2012).

Table 4. Effect of mineral $\mathrm{N}$, biofertilizer and compost on soil properties during 2010/2011 and 2011/2012 seasons.

\begin{tabular}{|c|c|c|c|c|c|c|c|c|c|c|c|c|}
\hline \multirow{2}{*}{ Treatment } & \multirow{2}{*}{$\begin{array}{c}\mathrm{pH} \\
{[1: 2.5]}\end{array}$} & \multirow{2}{*}{$\begin{array}{l}\mathrm{EC} \\
\mathrm{dSm}^{-1}\end{array}$} & \multicolumn{4}{|c|}{ cations $\mathrm{mmol}_{\mathrm{c}} \mathrm{L}^{-1}$} & \multicolumn{4}{|c|}{ anions $\mathrm{mmol}_{\mathrm{c}} \mathrm{L}^{-1}$} & \multirow{2}{*}{ SAR } & \multirow{2}{*}{ ESP } \\
\hline & & & $\mathrm{Ca}^{++}$ & $\mathrm{Mg}^{++}$ & $\mathrm{Na}^{+}$ & $\mathrm{K}^{+}$ & $\mathrm{Cl}^{-}$ & $\mathrm{CO}_{3}=$ & $\mathrm{HCO}_{3}^{-}$ & $\mathrm{SO}_{4}=$ & & \\
\hline & \multicolumn{12}{|c|}{ 2011-2012 } \\
\hline Control & 8.10 & 13.5 & 10.5 & 21.9 & 102 & 0.78 & 90.1 & nil & 8.26 & 42.3 & 25.4 & 36.6 \\
\hline N1 (119 kg N ha-1) & 8.08 & 12.7 & 13.7 & 18.1 & 85.6 & 0.79 & 78.2 & nil & 7.21 & 33.0 & 21.4 & 30.7 \\
\hline N2 (179 kg N ha $\left.{ }^{-1}\right)$ & 8.07 & 12.6 & 14.3 & 17.0 & 94.2 & 0.82 & 88.3 & nil & 6.22 & 32.2 & & 34.2 \\
\hline Bio & 8.04 & 10.3 & 12.0 & 17.5 & 82.2 & 0.83 & 75.2 & nil & 7.83 & 29.7 & & 0.6 \\
\hline$+\mathrm{N} 1$ & 8.01 & 10.5 & 14.3 & 16.2 & 72.0 & 0.93 & 63.1 & nil & 6.10 & 34.3 & & \\
\hline & 8.05 & 11.0 & 15.6 & 16.2 & 70.0 & 0.92 & 62.0 & nil & 5.69 & 35.1 & & 4.9 \\
\hline & 8.02 & 10.8 & 13.5 & 16.9 & 79.4 & 0.89 & 70.5 & nil & 6.49 & 34.2 & & 9.0 \\
\hline & 8.03 & & 12.4 & 16.9 & 83.8 & 0.86 & 77.4 & nil & 6.33 & 30.6 & & 1.4 \\
\hline & 8.00 & 11.4 & 15.8 & 16.0 & 74.7 & 0.96 & 60.6 & nil & 5.23 & 36.9 & & 6.6 \\
\hline & 8.05 & 11.6 & 13.6 & 17.4 & 82.7 & $\begin{array}{r}0.86 \\
201\end{array}$ & 73.9 & nil & 6.60 & 34.3 & & \\
\hline & 8.06 & & 14 & 19.7 & 98. & 0.82 & 82.4 & nil & 8.22 & 43.1 & & \\
\hline & 8.02 & 10.7 & 15.8 & 17.3 & 80. & 0.8 & 74.3 & nil & 7.17 & 39.5 & & \\
\hline N2 (179 kg N ha $\left.{ }^{-1}\right)$ & 8.02 & 11.5 & 15.8 & 17.1 & 73.1 & 0.85 & 66.1 & nil & 7.08 & 33.8 & & 25.6 \\
\hline Bio & 8.02 & 9.07 & 14.7 & 20.7 & 69.6 & 0.8 & 60.5 & nil & 6.35 & 33.5 & & 23.4 \\
\hline & 7.97 & 9.2 & 15.2 & 18.0 & 53.9 & 0.97 & 48.3 & nil & 5.42 & 37.3 & & 7.5 \\
\hline Bio + N2 & 8.00 & 10.6 & 15.4 & 17.2 & 58.5 & 0.93 & 49.4 & nil & 5.43 & 37.6 & 14 & 20.3 \\
\hline & 8.00 & & 17.7 & 18.2 & 56.6 & 0.94 & 52.1 & nil & 5.89 & 35.5 & & 18.6 \\
\hline Compost + N1 & 8.01 & 9.34 & 15.0 & 17.3 & 59.9 & 0.85 & 51.2 & nil & 6.28 & 35.8 & 14.9 & 20.9 \\
\hline & 7.95 & 9.39 & 17.8 & 17.0 & 50.7 & 0.95 & 42.0 & nil & 5.10 & 36.8 & 12.7 & 17.7 \\
\hline Grand Mean & 8.01 & 10.3 & 15.8 & 18.1 & 66.8 & 0.89 & 58.5 & nil & 6.33 & 37.0 & 16.3 & 22.9 \\
\hline
\end{tabular}




\section{Total soluble salts}

Data presented in Table 4 show that soluble salts decreased when the compost or bio-fertilizers were applied alone or in combination with $\mathrm{N}$ fertilizer. This would improve soil conditions for plant growth. Improvement in porosity and aggregation may have occurred due to the applied compost and biofertilizer and hence enhanced the leaching of salts (Zaka et al., 2005). The reclamation pre-treatments executed before carrying out the experiment enhanced the positive effect of bio and organic fertilization. Organic acids must have provided a substantial modification of soil physical properties, especially soil structure as well as soil aggregation and drainable pores. Consequently, these favorable conditions would positively affect soil permeability and encourage downward movement of water carrying Na-salts out of the soil. These results are in agreement with those of Bassiouny and Shaban (2010) and Rashed et al. (2011).

The lowest EC values (10.3 and $9.07 \mathrm{dSm}^{-1}$ ) were recorded with the treatment Bio $+\mathrm{N} 1$ at the first and second seasons, respectively. The used treatments could be arrange according to their effects on reducing EC of soil in the following descending order: Biofertilizer treatment when added solely or in combination with $\mathrm{N} 1$ and $\mathrm{N} 2$ followed by compost treatment when added solely or in combination with $\mathrm{N} 1$ and $\mathrm{N} 2$ and then mineral-N fertilization at the rates $\mathrm{N} 1$ and $\mathrm{N} 2$. This trend was found true for the two seasons. These results are in agreement with those obtained by Nasef et al. (2009) who found that beside of the improvement in soil aggregation caused by compost, its decomposition when combined with bio-fertilizers released acids therefore; such conditions facilitated leaching of soluble salts and decreased soil salinity.

\section{Soluble ions}

Data presented in Table 4 indicate that $\mathrm{Ca}^{++}$and $\mathrm{K}^{+}$increased while $\mathrm{Na}^{+}$ and $\mathrm{Mg}^{++}$decreased. The treatment (compost $+\mathrm{N} 2$ ) seemed to be generally of the most superior effect on $\mathrm{Ca}^{++}$and $\mathrm{K}^{+}$.

Soluble anions i.e., $\mathrm{Cl}^{-}, \mathrm{HCO}_{3}{ }^{-}$and $\mathrm{SO}_{4}{ }^{--}$decreased due to the bio, organic and mineral- $\mathrm{N}$ fertilization in soil after harvest for the two growing seasons 2011/2012 and 2012/2013. No free carbonates were detected in soil extracts. Bicarbonates which ranged from $8.26-5.23 \mathrm{mmol}_{\mathrm{c}} \mathrm{L}^{-1}$ for $2011 / 2012$ season and $8.22-5.10 \mathrm{mmol}_{\mathrm{C}} \mathrm{L}^{-1}$ for $2012 / 2013$ season were generally of the highest concentrations. Lowest value of $\mathrm{Cl}^{-}$and $\mathrm{HCO}_{3}{ }^{-}\left(60.6\right.$ and $5.23 \mathrm{mmol}_{\mathrm{c}} \mathrm{L}^{-1}$, respectively) at $2011 / 2012$ season and $\left(42.0 \mathrm{mmol}_{\mathrm{c}} \mathrm{L}^{-1}\right.$ and $5.10 \mathrm{mmol}_{\mathrm{c}} \mathrm{L}^{-1}$, respectively) at 2012/2013 season were obtained under (compost $+\mathrm{N} 2$ ), while for $\mathrm{SO}_{4}{ }^{-1}$ the treatment of biofertilization gave the lowest values (29.7 and 33.5 at 2011/2012 season and 2012/2013 season, respectively).

\section{Soil sodicity}

Soil sodicity in terms of exchangeable sodium percentage (ESP) of the soil as well as sodium adsorption ratio (SAR) of the soil paste extract, decreased considerably as affected by the fertilizer treatments (Table 4). Generally, all treatments resulted in a sharp decrease in SAR and ESP values. The SAR decreased from 25.4 for control to 17.6 for soil treated with Bio+N2, thus exhibiting a decrease of $30.7 \%$ in $2011 / 2012$ season. The SAR decreased from 23.8 (control) to 12.6 due to the treatment Bio $+\mathrm{N} 1$ 
Helmy, A. M. et al.

corresponding to a decrease performance of $47.1 \%$ in $2012 / 2013$ season. The ESP followed a trend similar to that of SAR which; the ESP values showed a decrease ranged between 32.0 to $48.7 \%$ due to the treatment (Bio + N2) in 2011/2012 and (Bio + N1) in 2012/2013 seasons, respectively.

Available macronutrients ( $N, P$ and $K$ )

Data presented in Table 5, show the available N, P and $\mathrm{K}\left(\mathrm{mg} \mathrm{kg}^{-1}\right)$ as affected by the used treatments and their combinations on the studied soil. Data revealed that available N, P and $\mathrm{K}$ increased as affected by the treatments of mineral, organic and bio and their combinations. Available $\mathrm{N}$ ranged between 33.1 to $56.1 \mathrm{mg} \mathrm{kg}^{-1}$ for $2011 / 2012$ season and 37.2 to $63.1 \mathrm{mg} \mathrm{kg}^{-1}$ for $2012 / 2013$ season. Available $\mathrm{P}$ ranged between 3.58 to 4.33 $\mathrm{mg} \mathrm{kg}^{-1}$ for $2011 / 2012$ season and 3.64 to $4.83 \mathrm{mg} \mathrm{kg}^{-1}$ for $2012 / 2013$ season. Available $\mathrm{K}$ ranged between 198 to $229 \mathrm{mg} \mathrm{kg}^{-1}$ in 2011/2012 season and 201 to $236 \mathrm{mg} \mathrm{kg}^{-1}$ in 2012/2013 season. The soil treated with compost $+\mathrm{N} 2$ gave the highest values of available $\mathrm{N}, \mathrm{P}$ and $\mathrm{K}$. The positive effect of organic $\mathrm{N}$ - source is partially due to a slow release of $\mathrm{N}$ from manure, as suggested by Bhandari et al. (2002).

Table 5. Available macro and micronutrients in soil after harvest during 2010/2011 and 2011/2012 seasons.

\begin{tabular}{|c|c|c|c|c|c|c|}
\hline \multirow[t]{2}{*}{ Treatment } & \multicolumn{3}{|c|}{$\begin{array}{l}\text { Available macronutrients } \\
\qquad\left(\mathrm{mg} \mathrm{kg}^{-1}\right)\end{array}$} & \multicolumn{3}{|c|}{$\begin{array}{c}\text { Available } \\
\text { micronutrients } \\
\left(\mathrm{mg} \mathrm{kg}^{-1}\right)\end{array}$} \\
\hline & $\mathbf{N}$ & $\mathbf{P}$ & $\mathbf{K}$ & $\mathrm{Fe}$ & Mn & Zn \\
\hline & \multicolumn{6}{|c|}{ 2011-2012 } \\
\hline Control & 33.1 & 3.58 & 198 & 6.53 & 2.58 & 0.96 \\
\hline N1 (119 kg N ha-1) & 44.2 & 3.72 & 193 & 6.76 & 2.66 & 0.98 \\
\hline N2 (179 kg N ha-1) & 47.2 & 3.80 & 198 & 6.83 & 2.72 & 1.00 \\
\hline Bio & 38.1 & 3.64 & 201 & 6.59 & 2.61 & 0.98 \\
\hline Bio + N1 & 48.2 & 4.22 & 215 & 7.12 & 2.89 & 1.07 \\
\hline $\mathrm{Bio}+\mathrm{N} 2$ & 50.1 & 4.26 & 219 & 7.16 & 2.96 & 1.08 \\
\hline Compost & 39.2 & 4.18 & 205 & 7.09 & 2.84 & 1.03 \\
\hline Compost + N1 & 52.1 & 3.77 & 222 & 7.63 & 2.65 & 0.98 \\
\hline Compost + N2 & 56.1 & 4.33 & 229 & 7.23 & 3.01 & 1.12 \\
\hline Grand Mean & 45.4 & 3.94 & 209 & 6.99 & 2.77 & 1.02 \\
\hline \multirow[t]{2}{*}{$\operatorname{LSD}_{0.05}$} & 3.62 & 0.34 & 2.03 & 0.12 & 0.18 & NS \\
\hline & \multicolumn{6}{|c|}{ 2012-2013 } \\
\hline Control & 37.2 & 3.64 & 201 & 5.63 & 2.65 & 1.02 \\
\hline N1 (119 kg N ha $\left.{ }^{-1}\right)$ & 46.2 & 3.78 & 204 & 6.74 & 2.77 & 1.06 \\
\hline N2 (179 kg N ha ${ }^{-1}$ ) & 53.4 & 3.89 & 207 & 6.79 & 2.82 & 1.09 \\
\hline Bio & 41.2 & 3.76 & 208 & 5.66 & 2.71 & 1.04 \\
\hline $\mathrm{Bio}+\mathrm{N} 1$ & 54.2 & 4.29 & 225 & 7.04 & 3.06 & 1.14 \\
\hline Bio + N2 & 59.1 & 4.76 & 232 & 7.08 & 3.12 & 1.15 \\
\hline Compost & 43.3 & 4.25 & 214 & 7.81 & 3.02 & 1.10 \\
\hline Compost + N1 & 57.0 & 3.80 & 229 & 5.71 & 3.07 & 1.06 \\
\hline Compost + N2 & 63.1 & 4.83 & 236 & 7.12 & 3.16 & 1.18 \\
\hline Grand Mean & 50.5 & 4.11 & 217 & 6.62 & 2.93 & 1.09 \\
\hline LSD $_{0.05}$ & 3.21 & 0.50 & 3.72 & 1.01 & NS & NS \\
\hline
\end{tabular}

The $\mathrm{P}$ and $\mathrm{K}$ fractions added through organic manures upon its decomposition with time may account for the increases in both $\mathrm{P}$ and $\mathrm{K}$. (Yadvinder et al., 2004). Also the production of organic and inorganic acids during the degradation of such organic materials (as well as humates) as a 
result of the microorganisms activities must have contributed to a decrease in soil $\mathrm{pH}$ which would reduce $\mathrm{K}$ fixation and produce more chelating ions, leading to an increase in available forms of elements in the rhizosphere zone. These results are in agreement with those obtained by Ewees and Abdel Hafeez (2010). The corresponding relative increases were $69 \%$ and $70 \%$ in $2011 / 2012$ and $2012 / 2013$ seasons for available $\mathrm{N}, 20.9 \%$ and $32.7 \%$ in $2011 / 2012$ and $2012 / 2013$ seasons for available $P$ and $15.7 \%$ and $17.4 \%$ in $2011 / 2012$ and $2012 / 2013$ seasons for available K. This was found to be obvious due true due to the treatment compost + N2.

\section{Available micronutrients ( $\mathrm{Fe}, \mathrm{Mn}$ and $\mathrm{Zn}$ )}

The concentrations of $\mathrm{Fe}$ and $\mathrm{Mn}$ in soil at the end of the experiment significantly increased due to application of compost, urea and biofertilizer in comparison with the untreated control treatment except for $\mathrm{Mn}$ in 2011/2012 season. Zn also increased due to the different treatments; however, the increases occurred were insignificant. This fact hold true for the two seasons under study. This may be due to the vital role of compost which contains microorganisms that make these nutrients more available in the soil. In addition, compost may play a vital role for increasing nutrients availability through the processes of chelating, biochemical processes and production of several organic acids during decomposition of compost as reported by Hammad and Abdel Ati (1998). Also, bacteria cause some micronutritive elements such as $\mathrm{Fe}, \mathrm{Mn}$ and $\mathrm{Zn}$ to release in available forms in soil through break down of organic materials in the soil (Bhande et al., 1997). The highest available $\mathrm{Fe}$ values $\left(7.63\right.$ and $\left.7.91 \mathrm{mg} \mathrm{kg}^{-1}\right)$ were obtained under the treatments of compost $+\mathrm{N} 1$ in 2011/2012 season and compost in 2012/2013 season, respectively. The highest available $\mathrm{Mn}$ and $\mathrm{Zn}$ contents in soil were 3.01 and $1.12 \mathrm{mg} \mathrm{kg}^{-1}$ soil in $2011 / 2012$ season and 3.16 and $1.18 \mathrm{mg} \mathrm{kg}^{-1}$ soil in 2011/2012 season, respectively and were obtained due to the treatment of compost $+\mathrm{N} 2$.

\section{Effect of treatments on growth parameters and yield of barley: Growth parameters}

Some growth parameters of barley plants are shown in Table 6. Application of urea, compost and biofertilizers solely or in combinations with urea significantly, increased grains weight per spike and 1000-grains weight of barley as compared to the untreated (control). This was found true for both the growing seasons 2011/2012 and 2012/2013, except for grain weight per spike in 2011/2012 season. The highest grain weight per spike and 1000grains weight were recorded in the plants treated with compost $+\mathrm{N} 2$ which caused increases of about $31.8 \%$ and $77.7 \%$ in $2011 / 2012$ season and $30.7 \%$ and $71.2 \%$ in $2012 / 2013$ season, respectively. Application of N1 (119 $\mathrm{kg} \mathrm{N} \mathrm{ha}^{-1}$ ) and N2 (179 kg N ha ${ }^{-1}$ ) increased grain weight per spike by $10.9 \%$ and $17.3 \%$ in $2011 / 2012$ and $12.3 \%$ and $16.7 \%$ in $2012 / 2013$, respectively and increased 1000-grain weight by $22.0 \%$ and $35.8 \%$ in $2011 / 2012$ and $18.6 \%$ and $30.7 \%$ in $2012 / 2013$, respectively. This shows the positive effect of urea which would enhance the decomposers of the organic matter thereby releases the nutrients in available form. Previous studies justified the positive effects of nitrogen application (Abedi et al., 2010 and Daneshmand et al., 2012) and biofertilizer inoculation (Kandil et al., 2011). 
Helmy, A. M. et al.

Table 6. Effect of urea, biofertilizer and compost on yield and yield components of barley during 2010/2011 and 2011/2012 seasons.

\begin{tabular}{|c|c|c|c|c|c|c|c|}
\hline \multirow{2}{*}{ Treatments } & \multirow{2}{*}{$\begin{array}{l}\text { Grain } \\
\text { weight } \\
\text { spike }^{-1} \\
\text { (g) }\end{array}$} & \multirow{2}{*}{$\begin{array}{l}\text { 1000- } \\
\text { grain } \\
\text { weight } \\
\text { (g) }\end{array}$} & \multicolumn{3}{|c|}{ Yield $\left(\mathrm{Mg} \mathrm{ha}^{-1}\right)$} & \multirow{2}{*}{$\begin{array}{c}\text { Yield } \\
\text { efficiency } \\
(\%)\end{array}$} & \multirow{2}{*}{$\begin{array}{c}\text { Harvest } \\
\text { index } \\
(\mathrm{HI}) \%\end{array}$} \\
\hline & & & Straw & Grain & Biological & & \\
\hline & \multicolumn{7}{|c|}{ First Season [2011-2012] } \\
\hline Control & 1.10 & 28.2 & 0.874 & 0.355 & 1.23 & 40.6 & 28.9 \\
\hline N1 (119kg N ha-1) & 1.22 & 34.4 & 1.86 & 1.19 & 3.05 & 64.0 & 39.0 \\
\hline N2 (179kg N ha $\left.{ }^{-1}\right)$ & 1.29 & 38.3 & 2.25 & 1.64 & 3.89 & 72.9 & 42.2 \\
\hline Bio & 1.15 & 35.5 & 0.960 & 0.702 & 1.66 & 73.1 & 42.3 \\
\hline $\mathrm{Bio}+\mathrm{N} 1$ & 1.30 & 41.3 & 2.52 & 2.29 & 4.81 & 90.9 & 47.6 \\
\hline $\mathrm{Bio}+\mathrm{N} 2$ & 1.38 & 48.1 & 2.81 & 2.59 & 5.40 & 92.2 & 48.0 \\
\hline Compost & 1.20 & 40.5 & 1.38 & 0.73 & 2.11 & 52.9 & 34.6 \\
\hline Compost + N1 & 1.36 & 46.2 & 2.72 & 2.52 & 5.24 & 92.7 & 48.1 \\
\hline Compost + N2 & 1.45 & 50.1 & 2.95 & 2.67 & 5.62 & 90.5 & 47.5 \\
\hline Grand Mean & 1.27 & 40.3 & 2.04 & 1.63 & 3.67 & 74.4 & 42.0 \\
\hline LSD $_{0.05}$ & NS & 3.341 & 0.173 & 0.320 & 3.691 & & \\
\hline & \multicolumn{7}{|c|}{ Second Season [2012-2013] } \\
\hline Control & 1.14 & 32.3 & 0.886 & 0.388 & 1.27 & 43.8 & 30.6 \\
\hline N1 (119kg N ha $\left.{ }^{-1}\right)$ & 1.28 & 38.3 & 1.96 & 1.25 & 3.21 & 63.8 & 38.9 \\
\hline N2 (179kg N ha ${ }^{-1}$ ) & 1.33 & 42.2 & 2.22 & 1.46 & 3.67 & 65.8 & 39.8 \\
\hline Bio & 1.22 & 35.2 & 0.993 & 0.733 & 1.73 & 73.8 & 42.4 \\
\hline $\mathrm{Bio}+\mathrm{N} 1$ & 1.36 & 44.4 & 2.58 & 2.35 & 4.93 & 91.1 & 47.7 \\
\hline $\mathrm{Bio}+\mathrm{N} 2$ & 1.42 & 52.2 & 2.85 & 2.69 & 5.53 & 94.4 & 48.6 \\
\hline Compost & 1.26 & 42.2 & 1.01 & 0.75 & 1.76 & 74.3 & 42.6 \\
\hline Compost + N1 & 1.43 & 51.4 & 2.61 & 2.36 & 4.97 & 90.4 & 47.5 \\
\hline Compost + N2 & 1.49 & 55.3 & 2.87 & 2.72 & 5.60 & 94.8 & 48.6 \\
\hline Grand Mean & 1.33 & 43.7 & 2.00 & 1.63 & 3.63 & 76.9 & 43.0 \\
\hline LSD $_{0.05}$ & 0.085 & 4.413 & 0.195 & 0.403 & 3.726 & & \\
\hline
\end{tabular}

\section{Straw and grains yields}

As shown in Table 6, $\mathrm{N}$ application, biofertilizer and compost as well as their combinations significantly, increased straw and grain yields of barley plants. The treatments followed the following descending order according to their effects on straw and grain yields: compost $+\mathrm{N} 2>$ Bio $+\mathrm{N} 2>$ compost + $\mathrm{N} 1>\mathrm{Bio}+\mathrm{N} 1>\mathrm{N} 2>\mathrm{N} 1>$ compost $>$ Bio $>$ control. This trend was found to be true for both the two growing seasons. The organic manure treated soil plots became more enriched in the released nutrient, especially the micronutrients, which directly or indirectly in valve in formation of starch, protein and other biological components through their roles in the respiratory and photosynthesis mechanisms as well as in the activity of various enzymes. In addition, the organic manure, leads to improve soil physicochemical, hydrological and biological characteristics, which facilitate nutrients uptake by barley, and hence increases barley straw and grain yields (Hegazi, 2004). Application of biofertilizer is suggested as a sustainable way for increasing crop yields due to the plant growth promoting substances produced by the biofertilizer (Joshi et al., 2012), in addition to the reasonable quantity of atmospheric nitrogen fixed by Rhizobium radiobacter (Namvar et al., 2012). Therefore, the general physiological status of the plants as indicated by the dry weight always exhibit positive response to use of 
biofertilizer. Piccinin et al., (2013) showed that the grain yield of wheat improved when wheat plants were grown with a combination of chemical $\mathrm{N}$ and biofertilizer inoculation. These results are in agreement with those obtained by Berhanu et al. (2013) and Namvar and Teymur (2013).

The highest straw and grain yields of 2011/2012 season (2.95 and 2.67 $\mathrm{Mg} \mathrm{ha}^{-1}$ ) and of $2012 / 2013$ season (2.87 and $2.72 \mathrm{Mg} \mathrm{ha}^{-1}$ ), respectively were obtained due to the addition of compost $+\mathrm{N} 2$ treatment which resulted in relative increments of $179 \%$ and $652 \%$ in $2011 / 2012$ season as well as $224 \%$ and $601 \%$ at $2012 / 2013$, respectively.

\section{Grain yield efficiency and harvest index}

Values of yield efficiency as affected by mineral, bio and organic- $\mathrm{N}$ whether applied solely or in combinations are shown in Table 6. Grain yield efficiency, which is the ratio of grain yield to straw yield at maturity varied between $40.6 \%-90.5 \%$ in the growing season of $2011 / 2012$ and $43.8 \%$ $94.8 \%$ in 2012/2013 growing season. The plants treated with compost $+\mathrm{N} 1$ gave the highest yield efficiency followed by biofertilizer + N2 treatment. The values were $92.7 \%$ and $92.2 \%$ for the season of $2011 / 2012$ giving increases of $128 \%$ and $127 \%$, respectively while the values were $94.8 \%$ and $94.4 \%$ observed under the treatments of compost $+\mathrm{N} 2$ and biofertilizer $+\mathrm{N} 2$ for the season of $2012 / 2013$ giving increases of $116 \%$ and $115 \%$, respectively.

Harvest index of barley increased due to the treatments urea, bio and compost solely or in combination with $\mathrm{N}$-fertilization. Harvest index of plants treated with compost $+\mathrm{N} 1$ in season 2011/2012 was the highest giving increase of $66.4 \%$ as compared to the control. The effects of compost + N2 and biofertilizer $+\mathrm{N} 2$ treatments were equal and gave almost the same highest value $(48.6 \%)$ in the growing season of $2012 / 2013$. The favorable effect of mineral $\mathrm{N}$ - fertilization is due to $\mathrm{N}$ being essential for plant growth. Therefore, the increase in $\mathrm{N}$-fertilization rate would increase metabolic processes and physiological activities rate, and thus, increased yield with good quality of grains would occur (Russel, 1973).

Total proline content

Data presented in Table 7, show the effect of nitrogen fertilization, biofertilization and compost on the total proline content in dry weight of grains. The plants received fertilizers showed significant decreases compared to the control (without fertilizers) which gave the highest proline contents 16.0 and $16.6 \mathrm{~g} \mathrm{~kg}^{-1}$ dry leaves in 2011/2012 and 2012/2013 seasons, respectively. These treatments can be arranged due to their effects on proline content in the following order: control $>\mathrm{N} 2>\mathrm{N} 1>$ compost $+\mathrm{N} 2>$ compost + $\mathrm{N} 1>$ biofertilizer $+\mathrm{N} 2>$ biofertilizer $+\mathrm{N} 1>$ compost $>$ biofertilizer. This trend was found true for $2011 / 2012$ and 2012/2013 seasons. Nour El-Din and Salama (2006) reported that proline accumulation is a common metabolic response of higher plants to salinity stress. Also, compost treatments decreased the proline accumulation in wheat plants grown in saline soil. These results agree with those obtained by Amirjani (2011) and Siam et al. (2013).

The biofertilizer inoculation with Rhizobium radiobacter sp. treatment decreased proline content by $23.8 \%$ and $29.5 \%$ at $2011 / 2012$ and $2012 / 2013$ seasons, respectively compared to the control. 
Helmy, A. M. et al.

\section{Grain protein content and protein yield}

It can be seen from results presented in Table 7 that the grain protein content and grain protein yield of barley significantly increased as affected by the treatments of urea, biofertilizer and compost and their combinations. Mabrouk (2002) found that bio-mineral and organic-mineral fertilization treatments were more effective in increasing protein content of peanut plants as compared with the individual mineral fertilization. The favorable effect of mineral $\mathrm{N}$-fertilization is attributed to its role as one of the most important constituents of all proteins and nucleic acids, and hence protoplasm and chlorophyll (Wortman et al., 2011). As the level of $\mathrm{N}$ - supply increases, the extra protein produced allows the plant leaves to grow larger and consequently photosynthesis increases; therefore, the increase in $\mathrm{N}$ fertilization level led to an increase in metabolic processes and physiological activities necessary for more plant organs formation, more dry matter accumulation and enhancing the grain hilling rate, which finally increase the amount of protein in grain. These results are in accordance with those reported by Abbas et al. (2011) and Joshi et al. (2012). The highest values of protein content (128 and $132 \mathrm{~g} \mathrm{~kg}^{-1}$ ) were obtained due to the treatment compost + N2 in 2011/2012 and 2012/2013 seasons representing increase percentage of $94.2 \%$ and $90.8 \%$, respectively.

Table 7. Effect of urea, biofertilizer and compost on concentration proline content, protein content and protein yield as well as $\mathrm{N}$ content and uptake by barley during 2010/2011 and 2011/2012 seasons.

\begin{tabular}{|c|c|c|c|c|c|c|c|}
\hline \multirow[t]{2}{*}{ Treatment } & \multirow{2}{*}{$\begin{array}{l}\text { Proline (g } \\
\left.\text { kg }^{-1}\right) \text { dry } \\
\text { weight }\end{array}$} & \multirow{2}{*}{$\begin{array}{l}\text { Protein } \\
\left(\mathrm{g} \mathrm{kg}^{-1}\right)\end{array}$} & \multirow{2}{*}{$\begin{array}{l}\text { Protein } \\
\text { yield } \\
\left(\mathbf{k g ~ h a}^{-1}\right)\end{array}$} & \multicolumn{2}{|c|}{$\begin{array}{c}\text { N content } \\
\left(\mathrm{g} \mathrm{kg}^{-1}\right)\end{array}$} & \multicolumn{2}{|c|}{$\begin{array}{l}\text { N uptake } \\
\left(\mathrm{kg} \mathrm{ha}^{-1}\right)\end{array}$} \\
\hline & & & & Straw & Grain & Straw & Grain \\
\hline & \multicolumn{7}{|c|}{$2011 / 2012$} \\
\hline Control & 16.0 & 65.9 & 23.4 & 7.97 & 11.3 & 6.96 & 4.61 \\
\hline N1 (119kg N ha $\left.{ }^{-1}\right)$ & 15.3 & 79.9 & 95.1 & 8.58 & 13.7 & 16.0 & 16.1 \\
\hline N2 (179kg N ha $\left.{ }^{-1}\right)$ & 15.4 & 85.7 & 141 & 9.68 & 14.7 & 21.8 & 24.0 \\
\hline Bio & 11.2 & 79.3 & 55.7 & 8.24 & 13.6 & 7.91 & 9.62 \\
\hline $\mathrm{Bio}+\mathrm{N} 1$ & 12.8 & 120 & 275 & 9.91 & 20.5 & 25.0 & 46.9 \\
\hline $\mathrm{Bio}+\mathrm{N} 2$ & 13.9 & 125 & 324 & 10.1 & 21.5 & 28.5 & 55.6 \\
\hline Compost & 12.2 & 88.0 & 64.2 & 8.54 & 15.1 & 11.8 & 11.0 \\
\hline Compost + N1 & 14.6 & 124 & 313 & 10.2 & 21.2 & 27.8 & 53.5 \\
\hline Compost + N2 & 14.9 & 128 & 342 & 10.8 & 22.0 & 31.9 & 58.6 \\
\hline Grand Mean & 14.0 & 101 & 182 & 9.34 & 17.3 & 19.7 & 31.1 \\
\hline LSD $_{0.05}$ & 0.141 & 0.875 & $\begin{array}{l}0.768 \\
2012\end{array}$ & $\begin{array}{l}0.074 \\
/ 2013\end{array}$ & 0.152 & 6.916 & 12.53 \\
\hline Control & 16.6 & 69.2 & 26.8 & 8.24 & 11.9 & 7.30 & 5.01 \\
\hline N1 (119kg N ha $\left.{ }^{-1}\right)$ & 15.9 & 82.8 & 104 & 8.86 & 14.2 & 17.4 & 17.7 \\
\hline N2 (179kg N ha ${ }^{-1}$ ) & 16.0 & 89.2 & 130 & 9.83 & 15.3 & 21.8 & 22.3 \\
\hline Bio & 11.7 & 80.8 & 59.2 & 8.64 & 13.9 & 8.58 & 10.4 \\
\hline $\mathrm{Bio}$ + N1 & 12.8 & 125 & 294 & 10.3 & 21.5 & 26.6 & 50.5 \\
\hline $\mathrm{Bio}+\mathrm{N} 2$ & 14.5 & 126 & 339 & 11.1 & 21.6 & 31.5 & 58.0 \\
\hline Compost & 12.3 & 88.2 & 66.2 & 9.17 & 15.1 & 9.24 & 10.6 \\
\hline Compost + N1 & 15.3 & 131 & 309 & 10.7 & 22.5 & 27.8 & 53.1 \\
\hline Compost + N2 & 15.5 & 132 & 359 & 11.3 & 22.6 & 32.3 & 61.6 \\
\hline Grand Mean & 14.5 & 103 & 187 & 9.78 & 17.7 & 20.3 & 32.1 \\
\hline LSD $_{0.05}$ & 0.170 & 1.322 & 0.987 & NS & 0.281 & 6.928 & 17.80 \\
\hline
\end{tabular}


Regarding the grain protein yield, results followed a trend similar to that of protein content and followed the sequence: compost $+\mathrm{N} 2>$ Bio $+\mathrm{N} 2>$ compost $+\mathrm{N} 1>$ Bio $+\mathrm{N} 1>\mathrm{N} 2>\mathrm{N} 1>$ compost $>$ Bio. This promoting effect could be attributed to the integrated effect of highly humified organic materials plus bio effect of nitrogen fixing bacteria on increasing the available nutrients and supporting them as a storehouse for plant growth against the adverse conditions e.g. high salinity and sodicity and accordingly maximizing the biological yield and grain quality of barley (Ewees and Abdel Hafeez, 2010). The highest values of protein content (342 and $\left.359 \mathrm{~kg} \mathrm{ha}^{-1}\right)$ were obtained due to the same treatment which resulted in the highest protein content in the two growing seasons, respectively.

Macronutrient content

Data in Tables 7 and 8 show that $\mathrm{N}, \mathrm{P}$ and $\mathrm{K}$ uptake increased significantly due to addition of urea, bio and organic- $\mathrm{N}$ sources and their combinations. Also, the treatment consisting of compost + N2 was superior for increasing the uptake of $\mathrm{N}, \mathrm{P}$ and $\mathrm{K}$ as compared to the other treatments. This promoting effect could be related to the $\mathrm{N}$ supplementary effect of $\mathrm{N}_{2}$ fixing bacteria (used as bio $\mathrm{N}$-fertilizer) to plants due to their ability to fix free molecular atmospheric nitrogen as well as the role of these bacteria in improving the availability of soil elements (Table 5) through secreting chelating substances (such as organic acids) which are important for solubilizing sparingly soluble inorganic compounds to more available forms for plants uptake (Kandil et al., 2011 and Daneshmand et al., 2012). On the other hand, the positive effect of organic manures might reflect the different characteristics of the added organic manures (their chemical composition and nutritional status). The organic manures might create favorable soil physical and chemical conditions, which affect the solubility and availability of nutrients and thus uptake of nutritional elements. Moreover, the released $\mathrm{N}$ is known to be an essential nutrient for plant growth and development involved in vital plant functions such as photosynthesis, DNA synthesis, protein formation and respiration (Diacono et al., 2013). These results coincide with the results of Abbas et al. (2011) and Namvar and Teymur (2013).

The individual effect of urea, compost and biofertilizer treatments showed a descending increase in the order: (N2 > N1 > compost $>$ biofertilizer) for N, P and K uptake by straw and grains during the growing season 2011/2012 and the same trend was found true at 2012/2013 season except for $\mathrm{K}$ uptake by straw which followed the order: (N2 > N1 > biofertilizer > compost). 
Helmy, A. M. et al.

Table 8. Uptake of $P$ and $K$ as well as $\mathrm{Fe}, \mathrm{Mn}$ and $\mathrm{Zn}$ by barley as affected by bio, mineral and organic- $\mathrm{N}$ fertilization during 2011/2012 and 2012/2013 seasons.

\begin{tabular}{|c|c|c|c|c|c|c|c|c|c|c|}
\hline \multirow{3}{*}{ Treatment } & \multicolumn{4}{|c|}{ Macronutrient uptake $\left(\mathrm{kg} \mathrm{ha}^{-1}\right)$} & \multicolumn{6}{|c|}{ Micronutrient uptake $\left(\mathrm{g} \mathrm{ha}^{-1}\right)$} \\
\hline & \multicolumn{2}{|r|}{$\mathbf{P}$} & \multicolumn{2}{|c|}{$\mathbf{K}$} & \multicolumn{2}{|c|}{$\mathrm{Fe}$} & \multicolumn{2}{|c|}{ Mn } & \multicolumn{2}{|c|}{$\mathrm{Zn}$} \\
\hline & Straw & Grains & Straw & Grains & Straw & Grains & Straw & Grains & Straw & Grains \\
\hline & \multicolumn{10}{|c|}{ 2011/2012 } \\
\hline Control & 1.95 & 1.19 & 23.4 & 4.98 & 46.2 & 27.7 & 27.3 & 15.6 & 12.6 & 7.32 \\
\hline N1(119kg N ha-1) & 4.64 & 4.09 & 51.2 & 17.1 & 121 & 103 & 68.7 & 58.2 & 35.2 & 35.2 \\
\hline N2(179kg N ha-1 & 6.38 & 5.90 & 65.2 & 24.1 & 161 & 154 & 95.5 & 85.9 & 48.2 & 51.3 \\
\hline Bio & 2.29 & 2.90 & 26.1 & 11.2 & 52.5 & 58.5 & 32.7 & 35.0 & 15.2 & 14.5 \\
\hline $\mathrm{Bio}+\mathrm{N} 1$ & 7.11 & 10.2 & 77.2 & 37.1 & 178 & 213 & 104 & 112 & 55.9 & 84.9 \\
\hline Bio + N2 & $8.55 c$ & 12.3 & 86.0 & 44.0 & 221 & 268 & 131 & 144 & 77.3 & 93.6 \\
\hline Com & 4.41 & 3.15 & 37.9 & 11 & 80.3 & 61.3 & 49.7 & 38.5 & 26.4 & 18.5 \\
\hline Co & 9.28 & 13.0 & 83.9 & 46. & 208 & 248 & 120 & 14 & 69.5 & 94.2 \\
\hline ost + N2 & 11.0 & 15.2 & 91.6 & 50.4 & 243 & 291 & 151 & 161 & 89.4 & 105 \\
\hline Grand Mean & 6.18 & 7.55 & 60.3 & & 146 & 158 & 86. & & 47.7 & 56.1 \\
\hline LSD 0.05 & 1.8 & \multicolumn{8}{|c|}{ 2012/2013 } & 28.18 \\
\hline Control & 2.21 & 1.33 & 23.9 & 5.53 & 47.1 & 30.9 & 29.3 & 18.2 & 13.5 & 8.37 \\
\hline N1(119kg N ha-1) & 6.14 & 5.1 & 56.0 & & 135 & 112 & & 67 & 42.1 & 40.6 \\
\hline N2(179kg N ha $\left.{ }^{-1}\right)$ & 7.34 & 5.93 & 64.6 & 22.0 & 165 & 138 & 97.8 & 79.8 & 51.5 & 51.0 \\
\hline Bio & 2.77 & 3.30 & 28.3 & 11.8 & 59.3 & 61.3 & 36.1 & 38.4 & 18.2 & 18.6 \\
\hline $\mathrm{Bio}+\mathrm{N} 1$ & 8.10 & 10.8 & 81.6 & 39.6 & 189 & 233 & 115 & 132 & 63.0 & 81.2 \\
\hline Bio + N2 & 10.0 & 14.1 & 89.0 & 46.2 & 235 & 285 & 143 & 156 & 86.4 & 103 \\
\hline Compost & 2.94 & 3.68 & 27.9 & 12.6 & 62.6 & 65.0 & 35.6 & 42.8 & 20.1 & 22.9 \\
\hline Compost + N1 & 8.97 & 12.8 & 82.0 & 43.5 & 207 & 249 & 126 & 142 & 71.5 & 86.3 \\
\hline Compost + N2 & 10.7 & 15.6 & 91.8 & 53.2 & 250 & 306 & 161 & 175 & 95.8 & 115 \\
\hline Grand Mean & 6.57 & 8.07 & 60.6 & 28.1 & 150 & 165 & 91.6 & 94.5 & 51.3 & 58.6 \\
\hline LSD 0.05 & 2.693 & 4.918 & 26.63 & 10.15 & 41.81 & 77.13 & 29.44 & 42.69 & 18.37 & 27.45 \\
\hline
\end{tabular}

The effect of compost and biofertilization in combinations with urea, on increasing $\mathrm{N}, \mathrm{P}$ and $\mathrm{K}$ uptake followed the order: (compost $+\mathrm{N} 2>$ biofertilizer + $\mathrm{N} 2>$ compost $+\mathrm{N} 1>$ biofertilizer $+\mathrm{N} 1$ ) for $\mathrm{N}$ uptake by straw and grains as well as $\mathrm{K}$ uptake by straw during the two growing seasons as well as $\mathrm{P}$ and $\mathrm{K}$ uptake by grains at the second season 2012/2013. However, the followed sequence: compost $+\mathrm{N} 2>$ compost $+\mathrm{N} 1>$ biofertilizer $+\mathrm{N} 2>$ biofertilizer $+\mathrm{N} 1$ characterized $\mathrm{P}$ and $\mathrm{K}$ uptake by grain at the first season and $\mathrm{P}$ uptake by straw at the second season.

The highest values of $\mathrm{N}, \mathrm{P}$ and $\mathrm{K}$ uptake during the two growing seasons were achieved due to application of compost $+\mathrm{N} 2$.

\section{Micronutrient contents}

Values of $\mathrm{Fe}, \mathrm{Mn}$ and $\mathrm{Zn}$ uptake by barely plants as affected by application of urea, compost and biofertilization solely or in combinations were shown in Table 8. The uptake of $\mathrm{Fe}, \mathrm{Mn}$ and $\mathrm{Zn}$ followed a pattern similar to that shown by the macronutrient where they increased significantly by the addition of the aforementioned fertilization treatments during the two growing seasons. Compost + N2 treatment was most effective on uptake of Fe, Mn and $\mathrm{Zn}$ as compared to the other treatments. This trend was found true for the two growing seasons 2011/2012 and 2012/2013. The percentages response of Fe, Mn and Zn uptake by barley straw over the control were 426, 453 and $610 \%$ in 2011/2012 and 431, 449 and $610 \%$ in $2012 / 2013$, respectively corresponding to 950 , 932 and $1334 \%$, 
respectively by barley grains in the first growing season and 890,862 and $1274 \%$ in the second growing season, respectively. These findings are in agreement with those reported by Ashmaye et al. (2008) and Nasef et al. (2009) who reported that the application of compost and bio-fertilizer combined with mineral $\mathrm{N}$ fertilizer caused pronounced increases in soil available micronutrients contents ( $\mathrm{Fe}, \mathrm{Mn}, \mathrm{Zn}$ and $\mathrm{Cu}$ ) during two season under rice cropping. These increases may be attributed to the role of organic sources in improving these micronutrients availability which was likely attributed to several reasons: i) Releasing of these nutrients through microbial decomposition of organic matter ; ii) Enhancing the chelation of metal ions by fulvic acid, organic legends and / or other organic function groups which may promote the mobility of metal from solid to liquid phase in the soil environment; iii) Lowering the redox statues of iron and manganese, leading to reduction of higher $\mathrm{Fe}^{3+} \& \mathrm{Mn}^{4+}$ to $\mathrm{Fe}^{2+}$ and $\mathrm{Mn}^{2+}$ and / or transformation of insoluble chelated forms into more soluble ions.

\section{Effect of the treatments on $\mathrm{N}$ utilization efficiencies}

The efficiency of applied $\mathrm{N}$ is considered important criterion beside the $\mathrm{N}$ requirements to obtain maximum economic yield. Accordingly, the efficiencies of the applied nitrogen for the different bio and organic treatments were calculated and the results were shown in Table 9.

\section{Nitrogen use efficiency (NUE) $\mathrm{kg} \mathrm{kg}^{-1}$}

The values of nitrogen use efficiency show that the inoculation with Rhizobium radiobacter $\mathrm{sp}$. increased NUE than the other treatments. On the other hand, application of compost decreased NUE obviously, and this may be because the nitrogen in the organic compost was not readily available for plant and, therefore the total $\mathrm{N}$ applied by fertilizer plus compost content (denominator) was much lower than the actual values. These results are in line with those obtained by Abbas et al. (2011) who found that the inoculation with B. japonicum increased NUE and nitrogen uptake efficiency compared with the uninoculated treatments. Also, the values of NUE markedly decreased as the nitrogen addition rate increased. Values of NUE ranged from $9.17-19.2$ at 2011/2012 season and $8.16-19.7$ at the second season 2012/2013. The highest NUE value $19.7 \mathrm{kgkg}^{-1}$ was obtained at the second growing season when plants urea treated with Rhizobium radiobacter plus the low rate of urea $\mathrm{N} 1\left(119 \mathrm{~kg} \mathrm{~N}^{-1}\right)$ which increased the efficiency use of urea fertilizer by $87.6 \%$ compared with the treatment received urea $\left(119 \mathrm{~kg} \mathrm{~N} \mathrm{ha}^{-1}\right)$ only.

Nitrogen agronomic efficiency (NAE) $\mathbf{~ k ~ k g ~}^{-1}$

The NAE parameter (the plants ability to increase the yield in response to $\mathrm{N}$ fertilization levels) $\mathrm{kg}$ grain / $\mathrm{kg} \mathrm{N}$ applied followed the same trend shown for the NUE and apparent nitrogen recovery (ANR) hence, the increase of $N$ rate decreased the NAE values. The above three traits which behaved similarly, showed that plants absorb more $\mathrm{N}$ when it is of low level in the soil. As the level of $\mathrm{N}$ increased the relative absorption of $\mathrm{N}$ went on decrease. The highest NAE values (13.3 and $13.6 \mathrm{~kg} \mathrm{~kg}^{-1}$ at 2011/2012 and 2012/2013 seasons, respectively) were obtained due to the treatment Bio + urea N1 $\left(119 \mathrm{~kg} \mathrm{~N} \mathrm{ha}^{-1}\right)$ which resulted in $90.5 \%$ and 88.4 increase percentages in the first and second growing seasons, respectively compared with the treatment received urea $\left(119 \mathrm{~kg} \mathrm{~N} \mathrm{ha}^{-1}\right)$. 
Helmy, A. M. et al.

\section{Apparent nitrogen recovery (ANR)}

The ANR parameter, which indicates the ability to increase $\mathrm{N}$ uptake in response to $\mathrm{N}$ applied and the proportions of fertilizer $\mathrm{N}$ recovered by the plants, was greatest when $119 \mathrm{~kg} \mathrm{~N}^{-1}$ was added in combination with bio inoculation of Rhizobium radiobacter compared to the other treatments and gave $31.3 \%$ and $33.7 \%$ recovery in the two growing seasons 2011/2012 and 2012/2013, respectively. This shows that the application of the low rate of nitrogen caused an enhancement of plant growth, causing the roots to explore a greater soil volume and absorb more $\mathrm{N}$ from the soil. The lower $\mathrm{N}$ recovery occurred at theN2 (179 $\mathrm{kg} \mathrm{N} \mathrm{ha}^{-1}$ ) rate indicates the considerable expansion of the root system in the rhizosphere and more $\mathrm{N}$ must have been released from the indigenous $\mathrm{N}$ in soil for plant uptake. The lower $\mathrm{N}$ recovery in compost treatment was due to lower uptake of $\mathrm{N}$ by grains compared to the other treatments.

Table 9. NUE, NAE $\left(\mathrm{kg} \mathrm{kg}^{-1} \mathrm{~N}\right)$ and ANR (\%) of barley as influenced by urea, compost and biofertilization during 2011/2012 and 2012/2013 seasons.

\begin{tabular}{|c|c|c|c|c|c|c|c|c|c|}
\hline Season & $\begin{array}{l}\overline{0} \\
\text { 을 } \\
\text { O }\end{array}$ & 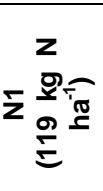 & 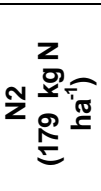 & $\stackrel{\circ}{m}$ & $\begin{array}{l}\bar{z} \\
+ \\
\text { 음 }\end{array}$ & $\begin{array}{l}\text { N } \\
+ \\
\stackrel{0}{m}\end{array}$ & $\begin{array}{l}\text { कू } \\
\text { 을 } \\
\text { हั }\end{array}$ & 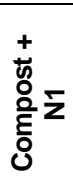 & 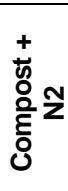 \\
\hline \multicolumn{10}{|c|}{ Nitrogen use efficiency, NUE (kg kg $\left.{ }^{-1} \mathrm{~N}\right)$} \\
\hline $2011 / 2012$ & 0.00 & 9.96 & 9.17 & 0.00 & 19.2 & 14.5 & 8.08 & 12.1 & 9.93 \\
\hline 2012/2013 & 0.00 & 10.5 & 8.16 & 0.00 & 19.7 & 15.0 & 8.34 & 11.3 & 10.1 \\
\hline \multicolumn{10}{|c|}{ Nitrogen agronomic efficiency, NAE $\left(\mathrm{kg} \mathrm{kg}^{-1} \mathrm{~N}\right)$} \\
\hline $2011 / 2012$ & 0.00 & 6.98 & 7.19 & 0.00 & 13.3 & 10.5 & 4.13 & 8.59 & 7.23 \\
\hline 2012/2013 & 0.00 & 7.22 & 5.99 & 0.00 & 13.6 & 10.9 & 4.03 & 7.72 & 7.35 \\
\hline \multicolumn{10}{|c|}{ Apparent nitrogen recovery, ANR (\%) } \\
\hline $2011 / 2012$ & 0.00 & 9.66 & 10.8 & 0.00 & 31.3 & 25.7 & 7.10 & 20.3 & 17.7 \\
\hline $2012 / 2013$ & 0.00 & 10.7 & 9.66 & 0.00 & 33.7 & 26.5 & 6.21 & 20.3 & 18.9 \\
\hline
\end{tabular}

The combined use of organic and inorganic nutrient sources may have contributed to better synchrony of nutrient availability to the crop, which was reflected in higher grain yield and biomass production. Also, the combined application of organic sources and fertilizer may provide more favorable conditions for plant growth. The use of organic sources provides not only nutrients in available forms but also organic matter, which is as an ecological method of sustaining soil productivity. Thus, it is suggested to use a combination of bio, organic and inorganic fertilizer to achieve the highest yield and best grain quality and ensure at the same time environmental conservation.

\section{CONCLUSION}

It could be concluded that application of bifertilizers and compost is very important due to their effect on improving soil physical, chemical and biological properties, besides compost represents a storehouse for all essential macro and micronutrients. The applied organic manure led to improve barley grain quality. Also, from the economical point of view, the use of organic manure decreases 
the needed amounts of chemical fertilizers produces higher yield and better quality of barley grains with a relatively lower coast. Finally, under the current experimental conditions, it could be concluded that this work hand granted evidence to the effective role of applied compost manure at the rate of $6 \mathrm{Mg} \mathrm{ha}^{-1}$ in combination with urea at the rate of $179 \mathrm{~kg} \mathrm{~N}^{-1}$ to achieve the greatest growth parameters, yield and quality of barley plants grown under salinity and sodicity stresses.

\section{REFERENCES}

Abbas, M.H.H., Ahmed, O.A.I., Manal, A.H. El-Gamal and Haythum, M.S. (2011). Integrated effect of mineral nitrogen, bio and organic fertilization on soybean productivity. Egypt. J. Biotechnol. 39: $43-63$.

Abdel-Fattah, M.K. (2012). Role of gypsum and compost in reclaiming saline sodic soils. ISOR J. Agric. and Veterinary Sci., 1(3): $30-38$.

Abedi, T., Alemzadeh A. and Kazemeini, S.A. (2010). Effect of organic and inorganic fertilizers on grain yield and protein banding pattern of wheat. Australian J. Crop Sci., 4(6): 384-389.

Amirjani, M.R. (2011). Effect of salinity on growth, mineral composition, proline content, antioxidant enzymes of soybean. American J. Plant Physiology 5: $360-360$.

Andrews, S.S. (2006). Crop residues removal for biomass production: Effects on soils and recommendations. Soil Quality National Technology Development Team USDA- National Resource Conservation Service.

Angas, P., Lampurlanes, J. and Martinez, C.C. (2006). Tillage and N fertilization effects on $\mathrm{N}$ dynamics and barley yield under semiarid Mediterranean conditions. Soil and Tillage Res. 87: $59-71$

Ashmaye, S.H., Shaban, Kh.A. and Abd El-Kader, M.G. (2008). Effects of mineral nitrogen, sulphur, organic and bio-fertilizer on maize productivity in saline soil of Sahl El-Tina. Minufiya, J. Agric. Res., 33(1): 195 - 209.

Baker, D. (1979). Report on cereal foods. J. Assoc. Off. Anal. Chem. 62: 369 370.

Bassiony, H.M and Shaban, Kh.A. (2010). Economic analysis for the efficiency use of mineral and bio-fertilizers on saline soil. Zagazig, J. Agric. Res. 37 (5): 1313- 1330.

Bates, L.S., Waldren, R.P. and Teave, I.D. (1973). Rapid determination of free proline for water stress studies. Plant and Soil, 939: 205-207.

Berhanu, G.W., Kismanyoky, T. and Sardi, K. (2013). Effect of nitrogen fertilization and residue management on the productivity of winter barley (Hordeum vulgare L.). Acta Agronomica Hungarica, 61(2): 101 111.

Bhandari, A.L., Ladha, J.K., Pathak, H., Padre, A.T., Dawe, D. and Gupta, R.K. (2002). Yield and soil nutrient changes in a long-term rice-wheat rotation in India. Soil Sci. Soc. Am. J., 66: 162-170.

Bhande, S.R., Sharma, S.B. and Chougule, A.B. (1997). Effected biofertilizer in combination with nitrogen through organic and inorganic sources on yield and quality of onion. National Hort. Res. Derelop. Found. 17(2):1-3. 
Helmy, A. M. et al.

Black,C.A., Evans D.D., White, I.I. Ensminger, L.E. and Clark, F.E. (1982). Methods of soil analysis. Amer. Soc. Agron. Inc., Ser. 9 in Agron., Madison, Wisconsin

Craswell, E.T. and Godwin , D.C. (1984). The efficiencies of nitrogen fertilizer applied to cereals in different climates. Adv. Plant Nutr. 1: 1-55

Daneshmand, N.G., Bakhshandeh, A. and Rostami, M.R. (2012). Biofertilizer affects yield and yield components of wheat. Inter. J. Agric. 2(6): 699704.

Diacono, M., Rubino, P. and Montemurro, F. (2013). Precision nitrogen management of wheat; a review. Agronomy for Sustainable Development. 33(1): $219-241$.

Doltra, J., Laegdsmand, M. and Olesen, J.E. (2011). Cereal yield and quality as affected by nitrogen availability in organic and conventional arable crop rotations: A combined modeling and experimental approach. Eur. J. Agron., 34: 83 - 95.

Echeverria, H.E. and Videla, C.C. (1998). Eficiencia fisiologica y de utilizacion de nitrogeno en trigo en la region pampeana Argentina. Ciencia del suelo 16: $83-87$

Ewees, M.S.A. and Abdel Hafeez, A.A.A. (2010). Response of maize grain yield to a partial substitution of $\mathrm{N}$-mineral by applying organic manure, bio-inoculation and elemental sulphur as an alternative strategy to avoid the possible chemical pollution. Egypt J. Soil Sci., 50(1): 141 166.

Hammad, A.M.M. and Abdel Ati, Y.Y. (1998). Reducing of nitrate and nitrite content of potato tublers via biofertilization with Azospirillum and VA Mycorrhizal fungi. J. Agric. Sci., Mansoura Univ. 23(6):2597-2610.

Hegazi, I.M.A. (2004). Maximizing wheat production in sandy soil by using some natural soil amendments. Egypt J. Appl. Sci., 19(4): $214-226$.

Jackson, M.L. (1958). Soil Chemical Analysis .Prentice- Hall, Inc., Englewood Califfs, New Jersy

Joshi, R.A., Prasanna, R., Shivay, Y.S. and Nain, L. (2012). Biofortification of wheat through inoculation of plant growth promoting rhizobacteria and cyanobacteria. Euro. J. Soil Biology., 50: 118 - 126.

Kandil, A.A., El-Hindi, M.H., Badawi, M.A., El-Morarsy, S.A. and Kalboush, F.A.H.M. (2011). Response of wheat to rates of nitrogen, biofertilizers and land leveling. Crop \& Enviro. 2(1): 46-51.

Kas, M., Haberletes, J. and Matejkov, S. (2010). Crop productivity under increasing nitrogen rates and different organic fertilization system in a long-term IOSDV experiment in the Czech Republic. Arch. Agr. Soil Sci. J., 56: $451-461$.

Krupenikov, I.A., Boincean, B.P. and Dent D. (2011). The black earth: Ecological principles for sustainable agriculture on chernozem soils. Springer Science, Business Media, London, UK. $143 \mathrm{p}$.

Lu, C., Ma, J., Chen, X., Zhang, X., Shi, Y. and Huang, B. (2010). Effect of nitrogen fertilizer and maize straw incorporation on $\mathrm{NH}_{4}{ }^{+}-{ }^{15} \mathrm{~N}$ and $\mathrm{NO}_{3}{ }^{-}$ $-{ }^{15} \mathrm{~N}$ accumulation in black soil of north east China among three consecutive cropping cycles. J. Soil Sci. Plant Nutr., 10: 443 - 453. 
Mabrouk, S.S. (2002). Response of some peanut cultivars to bio and organomineral fertilization. Zagazig J. Agric. Res., 29(6): 2071 - 2083.

Mann, L., Tolbert, V. and Cushman, J. (2002). Potential environmental effects of corn (Zea mays L.) stover removal with emphasis on soil organic matter and erosion: A review. Agric. Ecosyst. Environ., 89: 149 - 166.

Montemurro, F., Ferri, D. and Convertini, G. (2006). Nitrogen indicators, uptake and utilization efficiency in a maize and barley rotation cropped at different levels and sources of $\mathrm{N}$ fertilization. Field Crops Res., 99: 114-124.

Namvar, A., Khandan, T. and Shojaei, M. (2012). Effects of bio and chemical nitrogen fertilizer on grain and oil yield of sunflower (Helianthus annuus L.) under different rates of plant density. Annals Bio. Res., 3(2): $1125-1131$.

Namvar, A. and Teymur, K. (2013). Response of wheat to mineral nitrogen fertilizer and biofertilizer (Azotobacter sp. and Azospirillium sp.) inoculation under different levels of weed interference. Ekologija J. 59(2): 85 - 94.

Nasef, M.A., Shaban, Kh.A. and Abdel Hameed, A.F. (2009). Effect of compost and bio-fertilizer application on some chemical soil properties and rice productivity under saline soil condition. J. Agric. Mansoura Univ., 34 (4): 2609- 2623.

Nour El-Din, M. and Salama, A.S. (2006). Significance of biofertilization for improving yield, chemical and technological properties of wheat plants grown in saline soil. Zagazig J. Agric. Res., 33(3): $501-515$.

Omran, S.E.H., Eman, A.I.M. and El-Guibali, A.H. (2009). Influence of organic and Bio-fertilization on productivity, viability and chemical components of flax seeds. Egypt J. Soil Sci., 49(1): $49-64$.

Page, A.L., Miller, R.H. and Keeney, D.R. (1982). Methods of Soil Analysis. Part 2: Chemical and Microbiological Properties, $2^{\text {nd }}$ ed. Agronomy Society of America. Madison, WI.

Palm, C.A., Gachengo, C.N., Delve, R.J., Cadisch, G. and Giller, K.E. (2001). Organic inputs for soil fertility management in tropical agro ecosystems: application of an organic resources database. Agric. Ecosyst. Environ. 83(1-2): $27-42$.

Piccinin, G.G., Braccini, A.L., Dan, L.G.M., Scapim, C.A., Ricci, T.T. and Bazo, G.L. (2013). Efficiency of seed inoculation with Azospirillium brasilense on agronomic characteristics and yield of wheat. Industrial Crops and Products. 43: $393-397$.

Poraas, M.M.E., Salwa, A.I. Eisa, Shaban, Kh.A. and Sallam, A.M. (2008). Effect of applied organic and bio-fertilizers on the productivity and grains quality of maize grown in saline soil. Egypt J. Soil Sci., 48(4): $485-500$.

Rashed, F.M., Kesba, H.H., Saleh, W.D. and Moselhy, M.A. (2011). Impact of rice straw compost on microbial population plant growth nutrient uptake and root-knot nematode under greenhouse conditions. Afr. J. Agric. Res., 6: $1188-1203$.

Russel, E.W. (1973). "Soil conditions and plant growth". $10^{\text {th }}$ Ed., Longman Group Ltd., London.

Ryan, J., Garabet, S., Harmsen, K. and Rashid, A. (1996). "A soil and plant analysis". Manual Adapted for the West Asia and North Africa Region. ICARDA, Aleppo, Syria, 140. 
Helmy, A. M. et al.

Siam, H.S., Shaban, Kh.A. And Safaa, A.M. (2013). Evaluation of applying different mineral nitrogen sources on soil fertility and wheat productivity under saline soil conditions. J. Applied. Sci. Res., 9(4): 3146 - 3156.

Snedecor, G.W. and Cochran, W.G. (1971). Statistical Methods $6^{\text {th }}$ eddition. lowa State University Press, Ames. lowa, U.S.A.

Soltanpour, N. (1985). Use of ammonium bicarbonate - DTPA soil test to evaluate elemental availability and toxicity. Soil Sci. Plant Anal., 16: $323-338$.

Watanabe, F.S. and Olsen, S.R. (1965). Test of an ascorbic acid method for determing phosphorus in water and $\mathrm{Na} \mathrm{HCO}_{3}$ extracts from soil . Soil Sci. Soc. Am. Proc., 29 : 677 - 678

Wortman, S.E., Davis, A.S., Schutte, B.J. and Lindquist, J.L. (2011). Integrating management of soil nitrogen and weeds. Weed Sci., 59: $162-170$.

Yadvinder, S., Singh, B., Ladha, J.K., Khind, C.S., Gupta, R.K., Meelu, O.P. and Pasuquin, E. (2004). Long-term effects of organic inputs on yield and soil fertility in rice-wheat rotation. Soil Sci. Soc. Am. J., 68: $845-$ 853.

Zaka, M.A., Obaid, U.R., Rafa, H.U. and Khan, A.A. (2005). Integrated approach for reclamation of salt affected soils. J. Agric. and Soc. Sci., 1 (2): 94-97. 
كفـاءة التســيد النيتروجينـي للثـعير في الأراضسي الملحيـة الصـودية تحست تـأثير

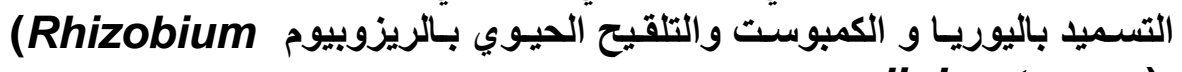

radiobacter sp.)

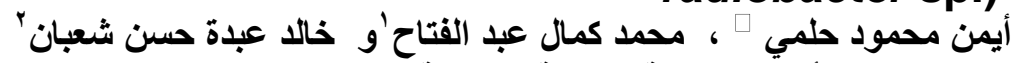

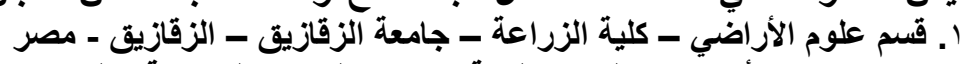

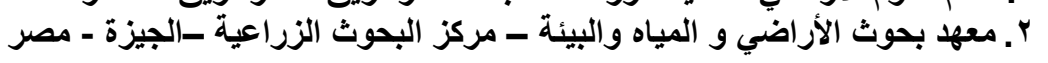

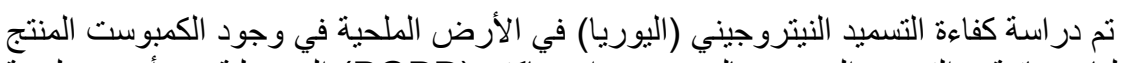

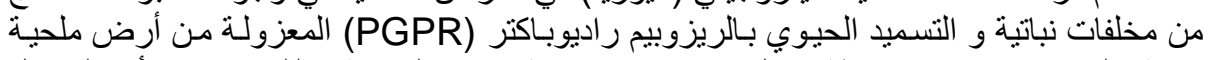

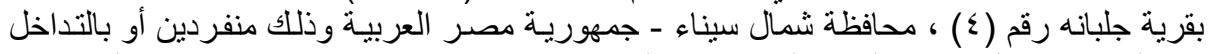

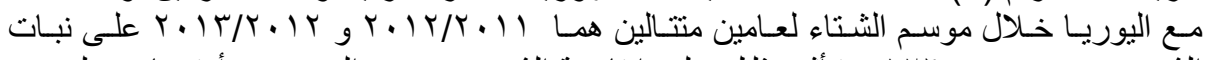

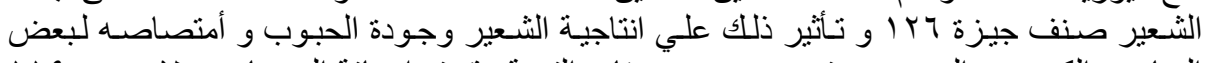

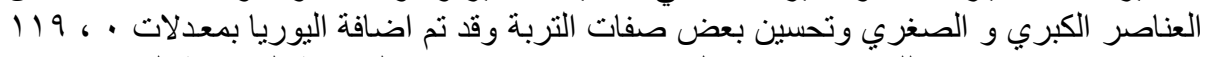

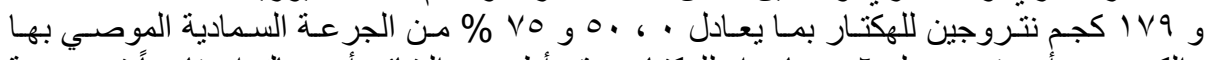

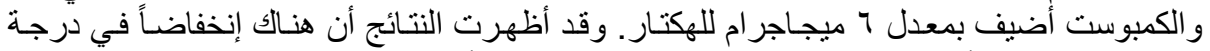

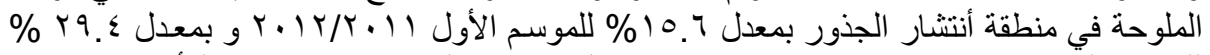

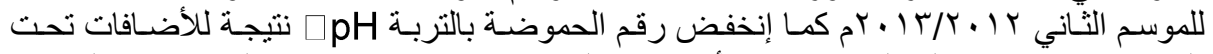

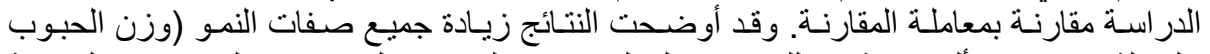

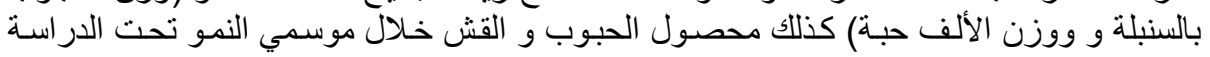

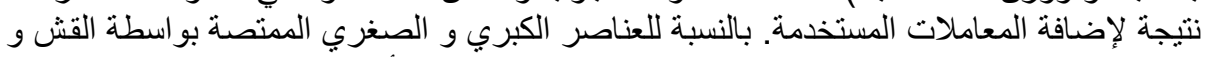

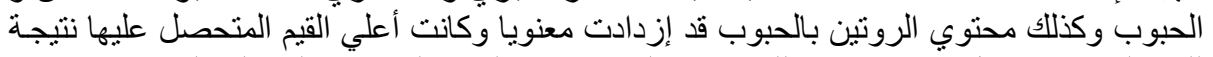

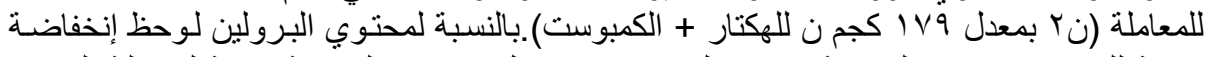

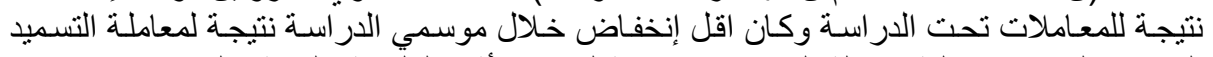

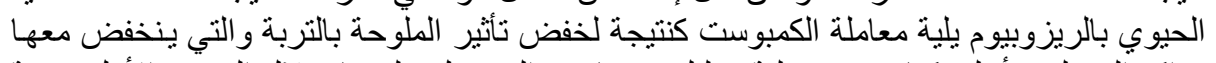

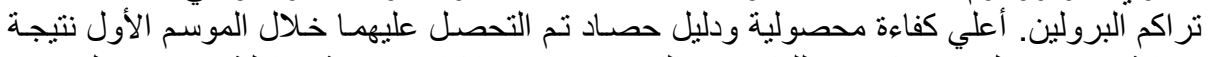

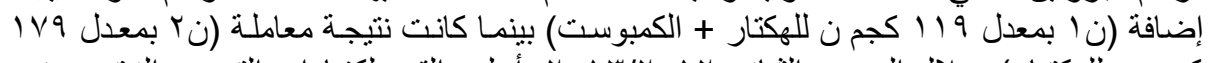

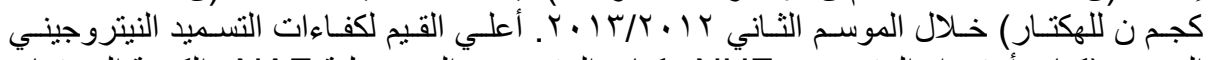

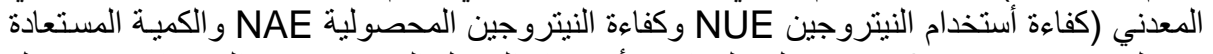

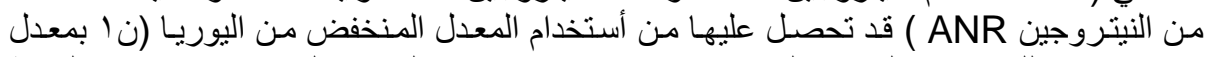

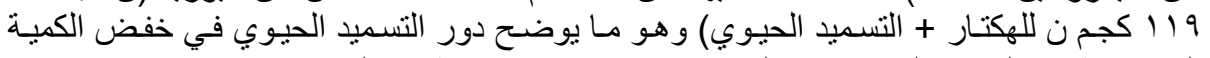

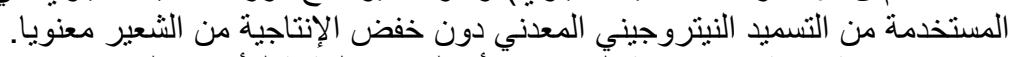

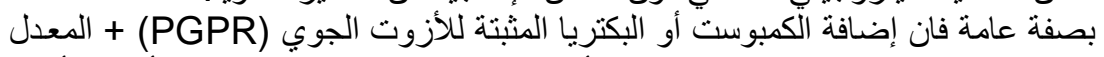

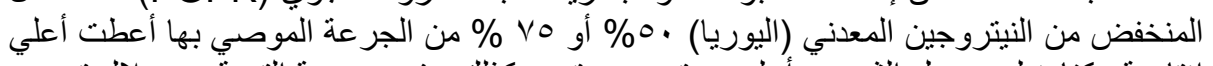

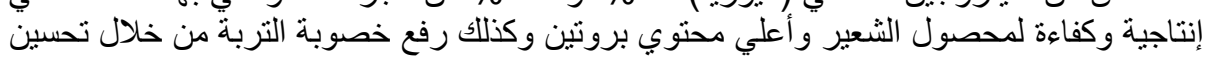
الصفات الطبيعية و الكيماوية و الحيوية بها.

كلية الزراعة - جامعة المنصورة كلية الزراعة بمشتهر - جامعة بنها
قام بتحكيم البحث

أ.د / أدمد عبد البد القادر طه

أ.د / حسن حمزه عبد الد طل 